\title{
Ten years into the marshes - Hapalemur alaotrensis conservation, one step forward and two steps back?
}

Antje Rendigs', Lena M. Reibelt', ", Fidimalala B. Ralainasolo', II, Jonah H. Ratsimbazafy', Iv, Patrick O. Waeberl, $\mathrm{V}$

\author{
Correspondence: \\ Antje Rendigs \\ Madagascar Wildlife Conservation \\ Ambatondrazaka, Madagascar \\ E-mail: antjerendigs@posteo.de
}

\begin{abstract}
Natural resource management problems typically involve a multitude of stakeholders with diverse sets of needs and interests, and often conflicting worldviews in an environment with growing uncertainty. Such problems are termed "wicked" problems, where there are no right or wrong solutions, only more or less acceptable ones. In the case of Lake Alaotra, growing agricultural pressures have a negative impact on the wetland biodiversity and especially on the Alaotra gentle lemur (Hapalemur alaotrensis) restricted to these marshlands. The species survival is highly uncertain because of increased habitat loss caused mainly by marshland fires. The conservation work for this unique lemur is complex and complicated and requires the involvement and collaboration of decision-making institutions, NGOs, universities and riverine communities. From the inception of projects to their implementation phase, all parties need clearly defined responsibilities and transparency in communication in order to run projects successfully. This article describes the approach that Madagascar Wildlife Conservation has been implementing during the past ten years at Lake Alaotra, discussing the plan of action and challenges for environmental education, ecotourism and alternative livelihoods.
\end{abstract}

\section{RÉSUMÉ}

Les problèmes de gestion des ressources naturelles impliquent généralement une multitude d'intervenants avec divers ensembles de besoins et d'intérêts, et souvent, les visions du monde contradictoires dans un environnement avec une incertitude croissante. Ces problèmes sont appelés problèmes sournois, 'wicked problems' en anglais, où il n'y a pas de bonnes ou de mauvaises solutions, seules plus ou moins acceptables. Dans le cas du lac Alaotra, la croissance des pressions agricoles a un impact négatif sur la biodiversité des zones humides, et en particulier sur l'Alaotra lémurien douce (Hapalemur alaotrensis) limitée à ces marais. La survie de l'espèce est très incertaine en raison de l'augmentation de la perte d'habitat causée principalement par les feux de marais. Les travaux de conservation pour ce lémurien unique sont complexes et compliqués, et nécessitent l'implication et la collaboration sur la prise de décision des institutions, des ONG, des universités et des communautés riveraines. Cela implique que toutes les parties, depuis la création de projets à leur phase de mise en œuvre, partagent un terrain d'entente avec les avantages clairement définis de pouvoir de décision, les responsabilités et la transparence dans la communication. Madagascar Wildlife Conservation a travaillé sur le lac depuis plus de dix ans, y compris l'éducation environnementale, l'écotourisme et les moyens de subsistance alternatifs dans le plan d'action. Cet article met en évidence l'approche adoptée et examine ses défis.

\section{INTRODUCTION}

Madagascar is renowned for its high endemic biological diversity, rich forests and a wealth of natural resources (Ganzhorn et al. 2001, Randriamalala and Liu 2010, Raharimahefa 2012). However, the country is also plagued by environmental degradation, low agricultural productivity and poverty; over $80 \%$ of the population lives below the poverty line of \$US 1.25 a day. The country ranks 151 out of 186 in the UNDP Human Development Index (UNDP 2013). Since 2009, political instability has further undermined economic development, amid a global financial crisis that has accentuated impacts on the poor, leading to increased food insecurity (Randrianja 2012). The political instability and the connected break-down in law and order has also directly weakened conservation efforts such as the prevention of rosewood trade (Schuurman and Lowry 2009, Innes 2010, Randriamalala and Liu 2010), or fuelled the crisis in the tortoise trade in the southwest of Madagascar (Hudson 2013). Furthermore, the country is at risk of increased 


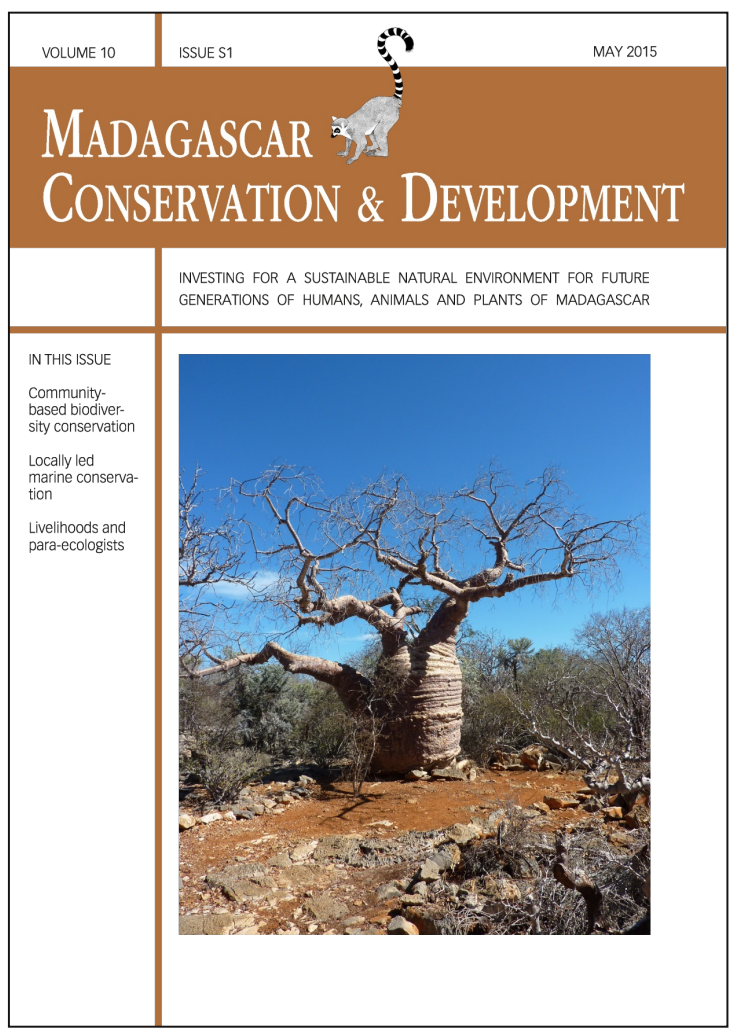

Madagascar Conservation \& Development is the journal of Indian Ocean e-Ink. It is produced under the responsibility of this institution. The views expressed in contributions to MCD are solely those of the authors and not those of the journal editors or the publisher.

All the Issues and articles are freely available at http://www.journalmcd.com

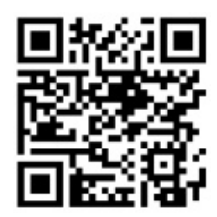

Contact Journal MCD

info@journalmcd.net for general inquiries regarding MCD funding@journalmcd.net to support the journal

Madagascar Conservation \& Development Institute and Museum of Anthropology

University of Zurich

Winterthurerstrasse 190

$\mathrm{CH}-8057$ Zurich

Switzerland

Indian Ocean e-Ink

Promoting African Publishing and Education

www.ioeink.com

Missouri Botanical Garden (MBG)

Madagascar Research and Conservation Program

BP 3391

Antananarivo, 101, Madagascar 
vulnerability and degradation from anticipated climate change (Hannah et al. 2008).

THE 'RICE BOWL' OF MADAGASCAR. Agriculture alone provides around $27 \%$ of GDP (gross domestic product), $40 \%$ of exports and ensures a living to about $75 \%$ of the Malagasy population (Institut National de la Statistique 2011). The primary economic driver in the two Lake Alaotra districts Ambatondrazaka and Amparafaravola is based on fishery and rice production, providing one third of the country's rice output (Andrianandrasana et al. 2005). The area is characterized by terraced, rice-growing valleys lying between grassy, deforested hills. There are three types of rice production: irrigated (surrounding the marsh belt of Lake Alaotra), rain-fed (on the hill slopes of the Alaotra basin), and contre-saison (within the marshlands of Lake Alaotra). The two lake districts are the biggest rice producing areas in the AlaotraMangoro, totaling 345,265 tons (irrigated production), 20,000 tons (rain fed) and 17,400 tons (contre-saison), respectively (Monographie Régionale 2012).

The (agro-) economic importance of the Alaotra-Mangoro (such as rice, fish, artisanal and industrial mining) has encouraged human migration into the region. The population has thus increased from some 110,000 people in the 1960s to nearly 550,000 in 2010 for the regions of Amparafaravola and Ambatondrazaka (Institut National de la Statistique 2012). The growing demand for arable land coupled with a continuously dwindling productivity per unit of agriculture (Bakoariniaina et al. 2006) is leading to increased destruction of marshlands, putting additional pressures on marshland biodiversity. The forests around Lake Alaotra have been replaced, probably post-LGM (last glacia maximum; Waeber et al. 2015a) by open landscapes showing the typical lavaka (erosion gully) features widespread in the region (Kusky et al. 2010). Some 250,000 zebus pasture the hill slopes (Ministère de l'Élevage 2013) contributing further to the exposed landscapes (for example, burning for fodder production, or mechanical trampling of soil). Downhill sedimentation and siltation are affecting Lake Alaotra by reducing its size, which ranges between 35-40 km length and 5-9 $\mathrm{km}$ width, depending on the season (Bakoariniaina et al. 2006). These erosion effects are accentuating the pressures also felt on the surrounding rice fields, for example reducing its productivity (Raharijaona-Raharison and Randrianarison 1999).

ALIEN PRESSURE. The water hyacinth (Eichhornia crassipes) originating from South America, is known as one of the most invasive plant species worldwide Villamanga and Murphy 2010). Reducing fish stock and diversity (e.g., Gratwicke and Marshall 2001), causing waterway clogging, but also worsening of water quality are some of the effects of E. crassipes invasion (see Mangas-Ramirez and Elias-Gutierrez 2004, Villamanga and Murphy 2010), which can cause also economic and social burden for the local population (Gunnarsson and Petersen 2007). Many fishing grounds are not accessible anymore and fishermen either have to invest in clearing waterways or burn further marshland vegetation for better access to fishing grounds. In the Alaotra wetland system, mostly endemic fish species are impacted by E. crassipes whereas exotic fish such as Tilapia spp. and more so Channa maculata can still persist in water with lower oxygen levels (Pidgeon 1996, Courtenay and Williams 2004).
MARSHLANDS AND ITS BIODIVERSITY DISAPPEARING 'IN A PUFF OF SMOKE'. Madagascar's forests have always been the focus of the international conservation community due to its rich biodiversity. That is, the high degree of endemism and level of threat found in these unique forests. Only since the beginning of the 2000s have wetlands begun receiving some conservation attention. Since 2003, Lake Alaotra and its wetlands were designated a Ramsar site (Ramsar site no. 1312), and in 2007 the area also received NAP status (Nouvelle Aire Protégée; new protected area; №381-2007/ MINENVEF/MAEP, 17 January 2007). Lake Alaotra is the largest freshwater lake in Madagascar and with an average depth of 1-2.5 $\mathrm{m}$ a shallow water body (Ferry et al. 2009).

The fringing marshland vegetation is dominated by reed (Phragmites communis) and cyperus (Cyperus madagascariensis and $C$. latifolius). Some unusual, endemic mammals have a narrow range limited to the lake, such as the Durrell mongoose (Salanoia durrelli), discovered in 2004 (Durbin et al. 2010) and the Alaotra gentle lemur (Hapalemur alaotrensis). This is the only swampdwelling primate (Mutschler et al. 2001, Waeber et al. 2015b). Genetically a congener of the forest-dwelling Hapalemur griseus, $\mathrm{H}$. alaotrensis is ecologically adapted to marshland conditions (Mutschler and Feistner 1995, Mutschler et al. 2001, Mutschler 2002, Waeber et al. 2015c). However, the future of this primate, classified by the IUCN as Critically Endangered (IUCN 2013a), is highly uncertain given the continuously growing pressures on the marshland ecosystem, mainly in the form of marshland fires (Guillera-Arroita et al. 2010a, b, Ratsimbazafy et al. 2013a); the last population estimations from 2005 reported numbers below 3,000 individuals (Ralainasolo et al. 2006).

This article presents ten years of conservation efforts at Lake Alaotra, analyzing the conservation approach taken by Madagascar Wildlife Conservation (MWC), which is based on a multilayered community involvement. The findings are critically discussed, including which approaches worked and especially which did not, serving to share MWC's experiences in wildlife and conservation management.

\section{STRATEGIES AND OBJECTIVES}

The Alaotra wetlands, important agriculturally and host to unique fauna represent a complex and complicated system (sensu Pietronero 2008). The challenge is seeking a balance between conservation and development or as Murphree (2002: 2) states "if conservation and development could be simultaneously achieved, the interest of both could be served (...)". By ensuring the maintenance of marshland ecosystem services and function, both the livelihood of the riverine communities as well as the survival of Hapalemur alaotrensis could be served. A positive example of achieving this is the temporary fishing closure around Lake Alaotra (15 November-15 January). The result was an increase in fish size and with that corresponded improved prices at the local markets, at least during the period 2002-2008 (J. Randriamahefasoa pers. observ.). Acting in a complex system requires the analysis of various scales and value-dimensions simultaneously in order to avoid the 'one correct perspective' (Berkes 2004). There are many different actors, each with their own value system, needs and agendas. To address this 'wicked problem' (sensu Rittel and Webber 1973), MWC pursues a multilayered, multipurpose and transdisciplinary approach (cf. Sayer et al. 2008, Selman 2009), with the following strategies and objectives: 
Prioritizing conservation zones: The Park Bandro (local name of the Alaotra gentle lemur) is situated in the marshes of the village Andreba Gare and is classified as Zone Prioritaire de Conservation (priority conservation zone; ZPC), which is the highest conservation category within the NAP. Within an area of 85 hectares, it shelters the highest density of $H$. alaotrensis found in the Alaotra region (Ratsimbazafy et al. 2013a). The high population size can be attributed to the protected zone, which allows for continuous reproduction but prevents migration due to its isolation. The objectives of this conservation strategy are to (i) maintain a core sub-population that can act as a source, or population pool, for linking with other sub-populations, (ii) showcase the natural habitat for the people of Andreba and other villages; this park can act as an 'open class-room' for various resource user groups; and, (iii) attract tourists who are interested in a unique primate that thrives in marsh habitat. The ultimate and overall goal of this park is to increase the chances of the survival of the lemur in its natural environment.

Valuing the 'Bandro': By promoting the flagship species $H$. alaotrensis, tourists can visit the region and hence create loca value for an intact marshland ecosystem (see Durbin 1999, Feistner 1999, Thalmann 2006, Durbin et al. 2007). The Camp Bandro just outside the village Andreba Gare and close to the lake provides five bungalows, one cafeteria, and sanitation facilities. The ecotourism infrastructure in place allows community members to source additional income (for example, by working as guides, cooks and providing accommodation). This model results in benefits for individual members and has indirect benefits to the entire community.

Increasing environmental awareness: This strategy focuses its efforts on the main future resource users: primary school children who are encouraged to learn, take interest, appreciate and understand their environment. Education is a prerequisite for a better standard of living as well as a founding contributor towards wildlife conservation (UNDP 2013). The school children around Lake Alaotra are motivated to engage actively in the sustainable use of their natural and agricultural resources through educational comic books and posters used in the school lessons, interactive material for group work and excursions onto the lake. Environmental education increases awareness towards environmental issues, raises public sensitivity and appreciation for the importance of an intact lake and preserved marshes and offers ideas for positive action (Ehrlich et al. 2008, MENRS 2008). Teachers naturally play a key role in education delivery and receive regular trainings.

Encouraging new perspectives: A majority of community members sustain their livelihood through different sources. In order to ease the pressure of marshland natural resources, one objective is to identify potential resources (What kind of resources are un-used so far?) and test new resources that are available and accessible to a majority of the community (What is technically and economically feasible? What is socially and culturally acceptable?). The invasive Eichhornia crassipes represents a promising option for alternative or supplement sources of income.

\section{IMPLEMENTATION}

LINKING MARSHLAND CONSERVATION AND TOURISM: HOW TO ENGAGE COMMUNITIES? In 2004, 85 hectares of intact and dense marshland vegetation were put under protection by DREF with the support of the Durrell Wildlife Conservation Trust in the Andreba fokontany (village). Park Bandro hosts the biggest Hapalemur alaotrensis sub-population with an estimated 170 individuals (Ratsimbazafy et al. 2013a).

The VOI (vondron' olona ifotony, community-based natural resource management association), founded in 2001, is responsible for the management of the park, which comprises maintenance of the canals (such as freeing them from Eichhornia crassipes, other congestive vegetation and mud) as well as regular patrolling to enforce park boundaries. The park can be accessed by pirogues and likely offers the prime viewing location for $\mathrm{H}$. alaotrensis.

In 2005, MWC started its ecotourism project. Ecotourism has the potential to increase the acceptance of a protected area, as it offers an alternative source of income to the people of the adjacent villages (Ormsby and Kaplin 2005). The guides who collaborate with MWC have been trained, and collaborative initiative with the local VOI has been established to ensure benefits for villagers. For each boat visiting the park, the VOI receives a portion of income that contributes to park management. In a subsequent phase, Camp Bandro is host to tourists that visit the park in early morning hours. The camp is presented in Sihanaka style (ethnic group from the Alaotra) and run by locals from the Andreba Gare community. Starting with 17 visitors in 2007 the number of tourists has gradually increased to over 50 per year. Additionally, the camp is used as a base for researchers working adjacent to Lake Alaotra as well as for workshops for local organizations. MWC also uses its income to support community-based microprojects. The local MWC Andreba section, together with representatives from the Andreba Gare community, prioritizes which community projects to support using the camp's revenue. Market stalls in Andreba's market place, pirogues (small boats) for the park visit, a soccer tournament, or the World Lemur Festival Andreba have so far been financially supported. During these community celebrations, MWC highlights the link between the intact marshes, Park Bandro, the Camp Bandro and the tourists that come to visit the area to view lemurs.

TARGETING FUTURE RESOURCE USERS. In 2006, MWC started

the Comic project Arovy fa harena (protecting natural wealth), producing comic books aimed at primary school-aged children in the Alaotra region to increase knowledge, understanding and awareness of the regional characteristics of the ecosystem and ecological relationships. In eight short episodes, the main characters (children and animals) introduce their respective worlds and values to each other in a manner that is accessible to children and culturally adapted to the region. The conservation messages include marsh burning, fishing, $\mathrm{H}$. alaotrensis biology, the importance of reed and Cyperus, and reforestation (cf. Maminirina et al. 2006). The comic books have been distributed in twelve elementary schools around the lake (Figure 1) and teachers have been trained during annual workshops in ecology, biodiversity, and environmental issues. To date, 100 teachers, school directors and members of the school authorities have been trained and 3,000 of the comic books have been distributed in schools around the lake.

To assess the impact of the comic books on school children's knowledge and understanding of ecosystem-related topics, an evaluation was conducted with structured questionnaires in a control group design with three survey periods; before, immediately following, and one year after introducing the comic 
books into the school program. Out of the 540 test pupils, one group per school was equipped with additional material encouraging interactive learning, while another group served as a control. That is, they did not have contact to the environmental education material. Initial analyses confirmed a trend of increased knowledge after the introduction of the comic books into the school lessons (Dolins et al. 2010); this effect has been increased when teachers used the supplementary interactive teaching material. Even after one year, the increased levels of knowledge were sustained, confirming teachers' anecdotal evidence that the comic books are still of utility. Some of the comic classes have been selected to visit Park Bandro during a school excursion to view $\mathrm{H}$. alaotrensis in its natural environment; the majority of children in the Alaotra region have never seen a lemur. This is generally the case across Madagascar (Ratsimbazafy 2003).

In order to complement the educational material, MWC developed an educational poster in collaboration with the McCrea Foundation, Durrell, UNICEF and the Ako Project in 2011 on which of Alaotra's biodiversity is presented. The benefits of a healthy environment - such as ecosystem services - for animals and humans are explained in Malagasy and English illustrating the characteristic fauna of the region. These posters have been distributed in all schools that are working with MWC. The latest MWC training in collaboration with ENS Antananarivo (École Normale Supérieure) and the participation of 35 teachers at the end of 2013 addressed, besides ecological and educational topics, how to implement the comic books and the educational posters into different school lessons such as Malagasy, French, geography and mathematics.

Current research carried out within the AMBio project, a collaboration between MWC and University of Hildesheim, Germany, focuses on a long-term and sustainable approach to providing environmental education in Alaotra's primary schools. Interviews and group meetings help assess the status quo of environmental education and identify drivers and barriers for further development (cf. Reibelt et al. 2014). The aim is to create interactive, locally and culturally-adapted teaching tools that will find wide-spread application due to their practicality, convenience and favorable cost-benefit-ratio thereby ensuring long-term utilization of the material.

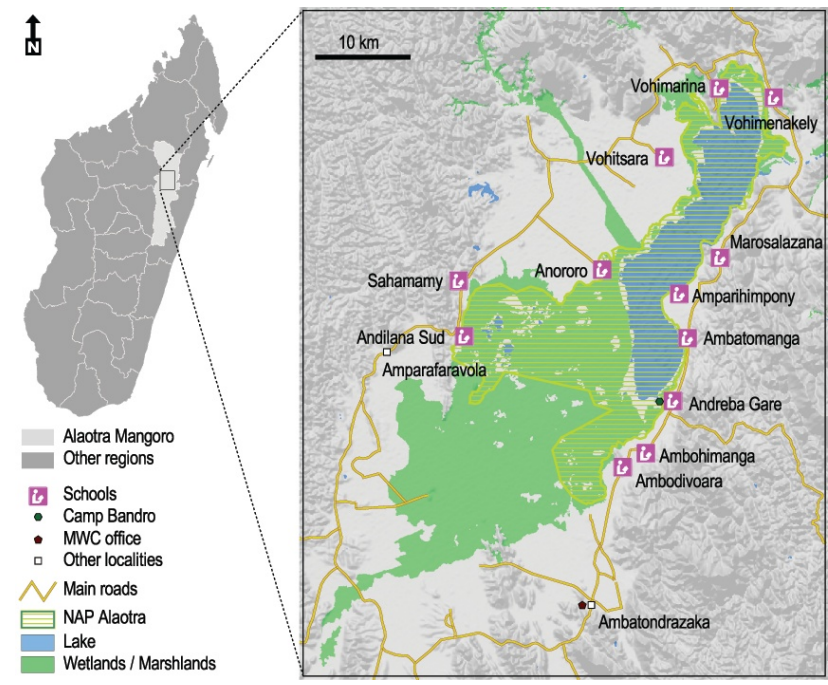

Figure 1. Location of public primary schools around Lake Alaotra engaged in the comic book project.
INVESTIGATING IN ALTERNATIVE RESOURCES USE. The Alaotra marshlands provide a range of important ecosystem services to the communities of adjacent villages. Zozoro or cyperus (Cyperus madagascariensis) and vohoaka (C. latifolius) are used for construction purposes and handicrafts; revaka or chick weed (Ageratum conyzoides) and tsy hita fototra or dodder (Cuscuta sinensis) are used as medicinal plants (for example, as a remedy for stomach complaints). Betsimihilana or water lily (Nymphaea $s p$.) is used in traditional ceremonies (for example, during the joro, a metaphysique ceremony to thank or consult with the zanahary (God) or the ancestors; S. H. N. H. Rakotoarimanana In lit.). The marshes host the breeding ground for fish, the main source of protein for the local population (Wallace 2012). They also act as natural filter and water reservoir (Andrianandrasana 2005) and play an important role in maintaining the hydrological balance in the Alaotra basin, crucial for rice production (Copsey 2009a).

Worldwide, several studies have dealt with the various options of using $E$. crassipes. The usage of this invasive plant represents a reasonable alternative to the costly and complex efforts to control it (Brendonck et al. 2003). Moreover, it offers an economic benefit. Despite its abundance, E. crassipes is only used marginally in the Alaotra. MWC has performed a first feasibility study in 2008 to investigate the potential of this invasive plant as a briquette and alternative to charcoal (Meier 2008). The lack of electricity, infrastructure and technical support make the E. crassipes an unrealistic option for charcoal. Using E. crassipes as a raw material for woven handicraft products (for example, baskets, place mats) did, however, show promise (ibid). The AMBio research (2012-2015) focuses on approaches that are likely to be successful in the Alaotra. For example, E. crassipes is suitable as fodder (Lu et al. 2008), can be used for production of compost (Gajalakshmi et al. 2001a, b, Malik 2006), and for braiding handicraft products (Lindsey and Hirth 2000, Jafari 2010). The ongoing research in AMBio thus focuses on improving and testing of handicraft products (for example, comparing different thicknesses and weaving techniques of E. crassipes). Aerobic and anaerobic compost experiments are being performed to assess the economic and technical feasibility and comparing the E. crassipes compost with commercially available fertilizers.

\section{CHALLENGES AND REMEDIATION MEASURES}

In this section it is discussed what approaches did not succeed during the ten years of conservation work with the communities, reasons are scrutinized and possible remediation measures are presented. Key to the following review are participation, communication, mutual respect and motivation.

UNDERSTANDING MARSHLAND FIRES. Since the early 1990s,

Durrell has been engaging mainly in the marshes of Andreba Gare to research the behavior and ecology of Hapalemur alaotrensis (Mutschler et al. 1998, Nievergelt et al. 1998, Mutschler et al. 2000, Nievergelt et al. 2002a, b, Waeber and Hemelrijk 2003). Since 2003, MWC and Durrell have been working collaboratively. The presence of researchers (mostly foreigners) and the engagement of locals in the various conservation and research projects have resulted in some effects: no fires for approximately 20 years have been registered in the marshlands of Andreba. However, fire events north and south of Andreba have steadily increased and represent a serious threat for the Park Bandro which is now isolated from other marshland patches 
(Ratsimbazafy et al. 2013a). Local explanations to marshland burning include the collection of the invasive fish species Channa maculata, the development of new rice fields, lemur hunting and accidental fires (Copsey et al. 2009b). In particular, the establishment of new rice fields poses a serious threat to the ecosystem as no regeneration of the marshland vegetation is possible following this disturbance. Currently, it is unclear whether local or external actors are responsible for initiating these fires. In addition, the presence of conservation bodies such as Durrell or MWC (who are accompanying the DREF, Direction Régionale des Eaux et Forêts, during the fire data collection) is not well received in some communities around Lake Alaotra. There is evident mistrust towards, or fear of potential repression from government representatives. Social disruption is also occurring. An example is given by the commune of Vohimarina in the north of the lake. Since April 2013, (coinciding with presidential elections campaign in Madagascar, cf. Waeber and Wilmé 2013) the community is split into a pro-conservation group and, opposingly, a group propagating the free access and redistribution of protected marshland for rice cultivation. In order to understand processes and interactions in the wetland system, the AlaReLa project (collaboration between MWC, École Supérieure des Sciences Agronomiques - ESSA Forêts, ETH Zurich, amongst other partners) addresses the marshland fire system and other changes in the wetlands following participatory action research (sensu Whyte 1991). Companion modeling (ComMod) is a community-based scientific approach to facilitate collective action (Bousquet et al. 1999, Barreteau et al. 2003). The first step of the Commod approach consists in collectively identifying a problem and an associated research question. Then the ARDI (Actors, Resources, Dynamics, Interactions) methodology is often deployed to analyze a problem and the involved components and processes (Etienne et al. 2011). The initial ARDI workshops around the lake have been promising as participants appreciate the opportunity to communicate freely without fearing consequences (Garcia et al. 2015).

PARK BANDRO MANAGEMENT. As part of a national target established by former President Ravalomanana to protect $10 \%$ of the country's terrestrial surface (Norris et al. 2006), 93 NAPs were identified in 2003 for key areas of biodiversity. The aim was to establish legal frameworks with state-approved management plans for the NAPs prior to May 2015. The creation of NAPS followed a national program of management transfers of natural resources from state control to local communities (GCF, Gestion Contractualisée des Forêts, forest management contracts, and GELOSE, Gestion Locale Sécurisée, secure local management), which has led to many communities taking over the management of habitat areas most often with extensive external NGO and financial support. In many cases, communities have lacked several of the core skills required to take on the management of these areas, which are official legal contracts between the communities and the government (Ratsimbazafy et al. 2013b, Pollini et al. 2014). To date, Alaotra went through the steps of undertaking environmental and social impact assessments (in 2010). However, a management plan, the most important strategic document towards official ratification, is still outstanding. These events coincided with the 2009 political crisis.

The Park Bandro, a priority conservation zone, represents a source of ongoing conflict between the different actors from the
Andreba Gare community. This is largely due to the lack of transparency and inequity in responsibility and decision-making surrounding management of the park. Anecdotal evidence suggests that the VOI, as the officially recognized steward of the Park Bandro, is having insider knowledge (i.e., being the sole actor involved in park delineation, without informing other stakeholders), and of having an exclusive understanding of how NAP operates. Some of the income generated from park entrance fees that were supposed to be reinvested into park maintenance have been diverted without clear explanation or have simply evaporated. The tourist Park Bandro guides have been switching between different associations, that is between MWC and Zetra Maitso (a local association). This has led to more confusion than clarity. "Equity and empowerment are often more important than monetary incentives for community-based conservation" (Berkes 2004: 629). To avoid competition between different associations in the future, it is envisioned to reorganize the guides under one single umbrella body, the DREF. These guides will be recognized as official and legitimate guides that will be subject to regular training following Madagascar National Park's ethical and structural guidelines. This will ensure that all guides are respectful towards park visitors, towards themselves and to the lemurs.

SOCIAL ACCEPTANCE AND LONG-TERM IMPACT. Hapalemur alaotrensis is used as a flagship species for MWC's ecotourism project. A community meeting was held with the tangalamena (village elder) prior to the onset of the project, to seek consent and approval of the project, but mostly to see whether there was actual interest in such a project. In MWC's environmental education program, targeting public primary schools, the CISCO and teachers have been consulted on potential interest in the comic book project. In both projects, there were strong indications in favor of beginning the respective projects.

A 'community', as stated by Carlsson (2000), consists of dynamic (evolving), cross scale, multi-dimensional and socialpolitical networks The fokonolona (this is known as the community where all residents register at the administrative subdivision within the village, aged eighteen years and older and residing in the district and territorial base of the village) is not a fixed or consistent entity for residents (cf. Pollini and Lassoie 2011). There is confusion and disagreement among members of the Andreba Gare community regarding decision-making and benefit-sharing in the ecotourism project. The camp has been established and funded by MWC. Some of the locals have found permanent salary positions, while others benefit by guiding occasional tourists. A majority, however, sees no benefit in having an ecotourism facility such as the Camp Bandro in the community, or they are indifferent to the initiative. Becoming part of the 'social landscape' is a process that will take time (cf. Richard and Ratsirarson 2013), meanwhile MWC is engaging different community groups to participate in a variety of activities in and around the Camp Bandro.

According to UNESCO's definition, 'environmental education' aims to increase awareness of the environment and the challenges it faces. Core to facilitating environmental education, knowledge, positive attitudes, motivation and skills are crucial (UNESCO 1975). In MWC's environmental education program, material such as comic books, teacher training and monitoring are sourced from outside of the system. This bares the risk that the 
project will cease when funding ends or any other external factor influences or disrupts education delivery. For the sustainable implementation of environmental education into the school program of the region, that is, to have a long-term impact on the future resource users, it is unavoidable to do a cost-benefit analysis. Within the realms of the AMBio project, research focuses on the CISCO institutional arrangement and the director and teacher level: using a participatory approach, tools are identified which are (i) replicable with locally available material at a low cost; (ii) complement or replace previous teaching material; (iii) are adapted to social and cultural conditions and teachers' needs.

\section{CONCLUSION}

One step forward and two steps back? The challenge in the conservation of Hapalemur alaotrensis lies in the complexity of the marshland social and local political systems. The conservation of the lemur species represents a typical 'wicked problem' with no singularly true or wrong solutions, only solutions that are better or worse, or more or less acceptable. An adaptive approach, or sometimes even a 'muddling through' (cf. Sayer et al. 2008) seems the likely and realistic approach for learning and bringing conservation efforts forward. This requires a holistic view of the system that targets problem areas in order to manage its inherent connectedness. To ensure success, conservation efforts are required to be scaled up to the entire marshland area and not center on few isolated communes. A concerted effort is hence required shouldered by a broad partnership of many different and diverse institutions and actors; the most important of which is the community. In this context, it is key that (i) management power and responsibilities are shared continuously and consistently, and (ii) a collaborative environment between the different actors is created that promotes learning and stewardship to ease mutual respect and trust.

Madagascar Wildlife Conservation's (MWC) attention in its early years concentrated exclusively around the promotion of awareness and appreciation of the Critically Endangered $H$. alaotrensis. In retrospect, MWC missed an opportunity to emphasize the need to fully comprehend the perspective of the community. In order to ground the conservation efforts, MWC is progressively acquiring a broad understanding of the various existing stakeholders and mapping and understanding their respective needs, values and power relations. Understanding the latter can help avoid misunderstandings and reduce the likelihood of friction between the various actors. Research projects like the AMBio or AlaReLa allow both sides, MWC and the communities, to listen and learn from and understand each other better. In complex management problems, different knowledge systems come with different value perspectives; Berkes (2009) suggests using both knowledge systems, academic and local as complementary, in 'dialogue and partnership'. In order to develop conservation strategies that find the support of the entire community for the long-run, continuous and transparent communication is key. The community should be involved at all project stages, from inception of a project (such as the conceptualization phase) through to the final stages. Using this approach, it is likelier that the community views their ownership within the process and sees tangible benefits in a project. However, it is of utmost importance to engage various segments of a community (acknowledging that the actor 'community' itself is a complex structure) within a project to circumvent perceptions of inequity in decision-involvement.

By using the 'ingredients' of mutual respect, shared and clearly defined responsibilities, transparent communication, in addition to ensuring the various incentives of shared decision making and benefits, all parties involved can be supportive of continued efforts to conserve $H$. alaotrensis.

\section{ACKNOWLEDGMENTS}

The authorities, CISCOs, primary school directors and teachers, and all the community members in the Alaotra region are acknowledged for supporting MWC's projects (www.madagascarwildlife-conservation.org). We thank Durrell for their collaboration on the ground, and numerous volunteers for their time and commitment to realize our projects. Our acknowledgements are extended to funding partners and our members for financial support of our projects on the ground, and to MCD's anonymous reviewers and the editors for their comments on a previous version of this manuscript.

\section{REFERENCES}

Andrianandrasana, H. T., Randriamahefasoa, J., Durbin, J., Lewis, R. E. and Ratsimbazafy, J. $\mathrm{H}$ 2005. Participatory ecological monitoring of the Alaotra wetlands in Madagascar. Biodiversity and Conservation 14, 11: 2757-2774. (doi:10.1007/s10531-005-8413-y)

Bakoarininiaina, L. N., Kusky, T. and Raharimahefa, T. 2006. Disappearing Lake Alaotra: Monitoring catastrophic erosion, waterway silting, and land degradation hazards in Madagascar using Landsat imagery. Journal of African Earth Sciences 44, 2: 241-252. (doi:10.1016/j.jafrearsci.2005.10.013)

Barreteau, O., Antona, M., D'Aquino, P., Aubert, S., Boissau, S. et al. (Collectif ComMod). 2003. Our companion modelling approach. Journal of Artificial Societies and Social Simulation 6, 1 : $<$ http://jasss.soc.surrey.ac.uk/6/2/1.html>

Berkes, F. 2004. Rethinking community-based conservation. Conservation Biology 18, 3: 621-630. (doi:10.1111/j.1523-1739.2004.00077.x)

Berkes, F. 2009. Indigenous ways of knowing and the study of environmental change. Journal of the Royal Society of New Zealand 39, 4:151-156. (doi:10.1080/03014220909510568)

Bousquet, F., Barreteau, O., Le Page, C., Mullon, C. and Weber, J., 1999. An environmental modelling approach: the use of multi-agent simulations. In: Advances in Environmental Modelling. F. Blasco and A. Weill (eds.), pp 113-122. Elsevier, Paris.

Brendonck, L., Maes, J., Rommens, W., Dekeza, N., Nhiwatiwa, T., et al. 2003. The impact of water hyacinth (Eichhornia crassipes) in a eutrophic subtropical impoundment (Lake Chivero, Zimbabwe). II. Species diversity. Fundamental and Applied Limnology 158, 3: 389-405. (doi:10.1127/0003-9136/2003/01580389)

Carlsson, L. 2000. Policy networks as collective action. Policy Studies Journal 28, 3: 502-520. (doi:10.1111/j.1541-0072.2000.tb02045.x)

Copsey, J. A., Rajaonarison, L. H., Randriamihamina, R. and Rakotoniaina, L. J. 2009a. Voices from the marsh: Livelihood concerns of fishers and rice cultivators in the Alaotra wetland. Madagascar Conservation \& Development 4, 1: 25-30. (doi:10.4314/mcd.v4i1.44008)

Copsey, J. A., Jones, J. P. G., Andrianandrasana, H., Rajaonarison, L. H., and Fa, J. E. 2009b. Burning to fish: local explanations for wetland burning in Lac Alaotra, Madagascar. Oryx 43, 3: 403-406. (doi:10.1017/\$0030605309000520)

Courtenay, W. R. and Williams, J. D. 2004 (eds.). Snakeheads (Pisces, Channidae): a biological synopsis and risk assessment. US Geological Survey Circular 1251, Denver, Colorado, USA.

Dolins, F. L., Jolly, A., Rasamimanana, H., Ratsimbazafy, J. H., Feistner, A. T. C. and Ravoavy, F. 2010. Conservation education in Madagascar: three case studies in the biologically diverse island! continent. American Journal of Primatology 72, 5: 391-406. (doi:10.1002/ajp.20779) 
Durbin, J. C. 1999. Lemurs as flagships for conservation in Madagascar. In: New Directions in Lemur Studies. B. Rakotosamimanana, H. Rasamimanana, J. Ganzhorn and S. Goodman (eds.), pp 269-281. Springer, USA.

Durbin, J. C., Rakotoniaina, L. J., Andrianandrasana, H. T. \& Randriamahefasoa, J. 2007. Projet Alaotra, utilisation d'espèces menacées en tant que porteétendard de la protection d'une zone humide avec les communautés locales. In: Paysages Naturels et Biodiversité de Madagascar. S. M. Goodman (ed.), pp 627-637. Muséum national d'Histoire naturelle, Paris.

Durbin, J., Funk, S. M., Hawkins, F., Hills, D. M., et al. 2010. Investigations into the status of a new taxon of Salanoia (Mammalia: Carnivora: Eupleridae) from the marshes of Lac Alaotra, Madagascar. Systematics and Biodiversity 8, 3 341-355. (doi:10.1080/14772001003756751)

Ehrlich, P. R. and Pringle, R. M. 2008. Where does biodiversity go from here? A grim business-as-usual forecast and a hopeful portfolio of partial solutions. Proceedings of the National Academy of Sciences of the United States of America 105, Supplement 1: 11579-11586. (doi:10.1073/pnas.0801911105)

Etienne, M., Du Toit, D. R. and Pollard, S. 2011. ARDI: a co-construction method for participatory modeling in natural resources management. Ecology and Society 16, 1: 44. <http://Www. ecologyandsociety.org/vol16/iss1/art44/>

Feistner, A. T. C. 1999. Conservation of the Alaotran gentle lemur, a multidisciplinary approach. In: New Directions in Lemur Studies. B. Rakotosamimanana, H. Rasamimanana, J. Ganzhorn and S. Goodman (eds.), pp 241-248. Springer, USA.

Ferry, L., Mietton, M., Robison, L. \& Erismann, L. 2009. Le lac Alaotra à Madagascar - passé, présent et futur. Zeitschrift für Geomorphologie 53, 3: 299-318. (doi:10.1127/0372-8854/2009/0053-0299)

Gajalakshmi, E. V., Ramasamy, S. A. and Abbasi, S. A. 2001a. Assessment of suitable vermiconversion of water hyacinth at different reactor efficiencies employing Eudrilus eugeniae Kingberg. Bioresources Technology 80, 2: 131-135. (doi:10.1016/S0960-8524(01)00077-3)

Gajalakshmi, E. V., Ramasamy, S. A. and Abbasi, S. A. 2001b. Potential of two epigeic and two anecic earthworm species in vermicomposting of wate hyacinth. Bioresources Technology 76, 3: 177-181. (doi:10.1016/S09608524(00)00133-4)

Ganzhorn, J. U., Lowry II, P. P., Schatz, G. E. and Sommer, S. 2001. The biodiversity of Madagascar: one of the world's hottest hotspots on its way out. Oryx 35,4 346-348. (doi:10.1046/j.1365-3008.2001.00201.x)

Garcia, C., Dray, A., Aubert, S., Reibelt, L. M. and Waeber, P. O. 2014 (In press). Scenarios of biodiversity exploring possible futures for management. Akon'ny Ala.

Gratwicke, B. and Marshall, B. E. 2001. The impact of Azolla filiculoides Lam. on animal biodiversity in streams in Zimbabwe. African Journal of Ecology 39 2: 216-218. (doi:10.1046/j.0141-6707.2000.00284.x.)

Guillera-Arroita, G., Lahoz-Monfort, J. J., Milner-Gulland, E. J., Young, R. P. and Nicholson, E. 2010a. Monitoring and conservation of the critically endangered Alaotran gentle lemur Hapalemur alaotrensis. Madagascar Conservation \& Development 5, 2: 103-109. (doi:10.4314/mcd.v5i2.63140)

Guillera-Arroita, G., Lahoz-Monfort, J. J., Milner-Gulland, E. J., Young, R. P. and Nicholson, E. 2010b. Using occupancy as a state variable for monitoring the Critically Endangered Alaotran gentle lemur Hapalemur alaotrensis. Endangered Species Research 11, 2: 157-166.

Gunnarsson, C. C. and Petersen, C. M. 2007. Water hyacinths as a resource in agriculture and energy production: A literature review. Waste Management 27. 1: 117-129. (doi:10.1016/j.wasman.2005.12.011)

Hannah, L., Dave, R., Lowry II, P. P., Andelman, S., Andrianarisata, M., et al. 2008. Climate change adaptation for conservation in Madagascar. Biology Letters 4, 5: 590-594. (doi:10.1098/rsbl.2008.0270)

Hudson, R. 2013. Troubled times for the radiated tortoise (Astrochelys radiata). Chelonian Research Monographs 6: 67-74. (doi:10.3854/crm.6.a13p67)

Innes, J. L. 2010. Madagascar rosewood, illegal logging and the tropical timber trade. Madagascar Conservation \& Development 5, 1: 6-10. (doi: 10.4314/mcd.v5i1.57335)

Institut National de la Statistique 2011. <http://www.instat.mg/> accessed 10 January 2012
Institut National de la Statistique. 2012. $<$ http://www.instat.mg/index.php?option=com_ content\&view $=$ article\&id=33\&/temid $=56>$ accessed 18 January 2014.

IUCN. 2013. The IUCN Red List. <http://www.iucnredlist.org/details/9676/0> accessed 18 January 2014

Jafari, N. 2010. Ecological and socio-economic utilization of water hyacinth (Eichhornia crassipes Mart Solms). Journal of Applied Sciences and Environmental Management 14, 2: 43-49. (doi:10.4314/jasem.v14i2.57834)

Kusky, T. M., Toraman, E., Raharimahefa, T. and Rasoazanamparany, C., 2010. Active tectonics of the Alaotra-Ankay Graben System, Madagascar. Possible extension of Somalian-African diffuse plate boundary? Gondwana Research 18, 2-3: 274-294. (doi:10.1016/j.gr.2010.02.003)

Lindsey, K. and Hirth, H.-M. 2000. Use Water Hyacinth! A Practical Handbook of Uses for the Water Hyacinth from Across the World. Anamed, Winnenden.

Lu, J., Fu, Z. and Yin, Z. 2008. Performance of a water hyacinth (Eichhornia crassipes) system in the treatment of wastewater from duck farm and the effects of using water hyacinth as duck feed. Journal of Environmental Sciences 20, 5: 513-519. (doi:10.1016/S1001-0742(08)62088-4)

Malik, A. 2006. Environmental challenge vis-à-vis opportunity: The case of water hyacinth. Environmental International 33, 1: 122-138. (doi:10.1016/j.envint.2006.08.004)

Maminirina, C. P., Girod, P. and Waeber, P. O. 2006. Comic strips as environmental educative tools for the Alaotra Region. Madagascar Conservation \& Development 1, 1: 11-14. (doi:10.4314/mcd.v111.44045)

Mangas-Ramirez, E. and Elias-Gutierrez, M. 2004. Effect of mechanical removal o water hyacinth (Eichhornia crassipes) on the water quality and biological communities in a Mexican reservoir. Journal of Aquatic Health and Management 7, 1: 161-168. (doi:10.1080/14634980490281597)

Meier, L. 2008. Bericht Machbarkeitsstudie Wasserhyazinthe. Unpublished Report. Madagascar Wildlife Conservation.

MENRS. 2008. Ministère de l'Éducation Nationale et de la Recherche Scientifique Éducation pour Tous - Madagascar.

Ministère de l'Élevage. 2013. Effectif du Cheptel dans la Région Alaotra-Mangoro: année 2010-2011. Unpub. Report. Direction Régionale de l'Élevage AlaotraMangoro.

Monographie Régionale. 2012. Monographie régionale Alaotra-Mangoro. Unpublished Report. Direction Régionale de l'Économie Alaotra-Mangroro.

Murphree, M. W. 2002. Protected area and the commons. Common Property Resource Digest 60: 1-3.

Mutschler, T. 2002. Alaotran gentle lemur: some aspects of its behavioral ecology. Evolutionary Anthropology: Issues, News, and Reviews 11, S1: 101-104. (doi:10.1002/evan.10068)

Mutschler, T. and Feistner, A. T. C. 1995. Conservation status and distribution of the Alaotran gentle lemur Hapalemur griseus alaotrensis. Oryx 29, 4: 267-274. (doi:10.1017/S0030605300021268)

Mutschler, T., Feistner, A. T. C. and Nievergelt, C. M. 1998. Preliminary field data on group size, diet and activity in the Alaotran gentle Lemur Hapalemur griseus alaotrensis. Folia Primatologica 69, 5: 325-330. (doi:10.1159/000021647)

Mutschler, T., Nievergelt, C. M. and Feistner, A. T. 2000. Social organization of the Alaotran gentle lemur (Hapalemur griseus alaotrensis). American Journal of Primatology 50, 1: 9-24. (doi:10.1002/(SICI)1098-2345(200001)50:1<9::AIDAJP2>3.0.CO;2-2)

Mutschler, T., Randrianarisoa, A. J. and Feistner, A. T. C. 2001. Population status of the Alaotran gentle lemur Hapalemur griseus alaotrensis. Oryx 35, 2: 152-157. (doi:10.1046/j.1365-3008.2001.00167.x)

Nievergelt, C. M., Mutschler, T. and Feistner, A. T. C. 1998. Group encounters and territoriality in wild Alaotran gentle lemurs (Hapalemur griseus alaotrensis) American Journal of Primatology 46, 3: 251-258. (doi:10.1002/(SICI)10982345(1998)46:3<251::AID-AJP5>3.0.CO;2-H)

Nievergelt, C. M., Pastorini, J. and Woodruff, D. S. 2002a. Genetic variability and phylogeography in the wild Alaotran gentle lemur population. Evolutionary Anthropology 11, S1: 175-179. (doi:10.1002/evan.10085) 
Nievergelt, C. M., Mutschler, T., Feistner, A. T. C. and Woodruff, D. S. 2002b. Social system of the Alaotran gentle lemur (Hapalemur griseus alaotrensis): genetic characterization of group composition and mating system. American Journal of Primatology 57, 4: 157-176. (doi:10.1002/ajp.10046)

Norris, S. 2006. Madagascar defiant. Bioscience 56, 12: 960-965. (doi:10.1641/0006-3568(2006)56[960:MD]2.0.CO;2)

Ormsby, A. and Kaplin, B. A. 2005. A framework for understanding community resident perceptions of Masoala National Park, Madagascar. Environmental Conservation 32, 2: 156-164. (doi:10.1017/S0376892905002146)

Pidgeon, M. 1996. An Ecological Survey of Lake Alaotra and Selected Wetlands of Central and Eastern Madagascar in Analyzing the Demise of Madagascar Pochard Aythya innotata. WWF/Missouri Botanical Garden, Antananarivo, Madagascar.

Pietronero, L. 2008. Complexity ideas from condensed matter and statistical physics. Europhysics News 39, 6: 26-29. (doi:10.1051/epn:2008603)

Pollini, J. and Lassoie, J. P. 2011. Trapping farmer communities within global environmental regimes: the case of the GELOSE legislation in Madagascar. Society and Natural Resources 24, 8: 814-830. (doi:10.1080/08941921003782218)

Pollini, J., Hockley, N., Muttenzer, F. D. and Ramamonjisoa, B. S. 2014. The transfer of natural resource management rights to local communities. In: Conservation and Environmental Management in Madagascar. I. Scales (ed.), pp172-192. Routledge, London and New York.

Raharijaona-Raharison, L. J. \& Randrianarison, J. 1999. Facteurs géologiques et climatiques influençant l'érosion en lavaka et ensablement des rizières: le cas du massif d'Ambohitrandriampotsy du sud du Lac Alaotra. In: Actes du 4e colloque international organisé par l'Association pour les Montagnes Africaines (AMA). H. Hurni \& J. Ramamonjisoa (eds.), pp 159-172. Association pour les Montagnes Africaines, Antananarivo.

Raharimahefa, T. 2012. Geoconservation and geodiversity for sustainable development in Madagascar. Madagascar Conservation \& Development 7 3: 126-134. (doi:10.4314/mcd.v7i3.5)

Ralainasolo, F. B., Waeber, P. O., Ratsimbazafy, J., Durbin, J and Lewis, R. 2006. The Alaotra gentle lemur. Population estimation and subsequent implications. Madagascar Conservation \& Development 1, 1: 9-10 (doi:10.4314/mcd.v1i1.44044)

Randriamalala, H. and Liu, Z. 2010. Rosewood of Madagascar: Between democracy and conservation. Madagascar Conservation \& Development 5 , 1: 11-22. (doi:10.4314/mcd.v5i1.57336)

Randrianja, S. (ed.) 2012. Madagascar, le coup d'État de mars 2009. Éditions Karthala, Paris.

Ratsimbazafy, J. H. 2003. Lemurs as the most appropriate and best didactic tool for teaching. Lemur News 8: 19-21.

Ratsimbazafy, J. H., Ralainasolo, F. B., Rendigs, A., Mantilla Contreras, J., Andrianandrasana, H., et al. 2013a. Gone in a puff of smoke? Hapalemur alaotrensis at great risk of extinction. Lemur News 17: 14-18.

Ratsimbazafy, J. H., Gore, M. L. and Rakotoniaina, L. J. 2013b. Madagascar. In: Community Policing in Indigenous Communities. M. K. Nalla and G. R. Newman (eds.), pp 31-39. CRC Press, Taylor \& Francis Group, Boca Raton, Florida.

Reibelt, L. M., Richter, T., Waeber, P. O., Rakotoarimanana, S. H. N. H. and Mantilla Contreras, J. 2014. Environmental education in its infancy at Lake Alaotra, Madagascar. Madagascar Conservation and Development 9, 2: 71-82. (doi:10.4314/mcd.v9i2.3)

Richard, A. F. and Ratsirarson, J. 2013. Partnership in practice: making conservation work at Beza Mahafaly, southwest Madagascar. Madagascar Conservation \& Development 8, 1: 12-20. (doi:10.4314/mcd.v8i1.3)

Rittel, H. W. J. and Webber, M. M. 1973. Dilemmas in a general theory of planning. Policy Sciences 4, 2: 155-169. (doi:10.1007/BF01405730)

Sayer, J., Bull, G. and Elliott, C. 2008. Mediating forest transitions: 'Grand design' or 'muddling through'. Conservation and Society 6, 4: 320-327. (doi:10.4103/0972-4923.49195)

Schuurman, D. and Lowry II, P. P. 2009. The Madagascar rosewood massacre. Madagascar Conservation \& Development 4, 2: 98-102. (doi:10.4314/mcd.v4i2.48649)
Selman, P. 2009. Planning for landscape multifunctionality. Sustainability: Science, Practice \& Policy 5, 2: 45-52.

Thalmann, U. 2006. Lemurs - ambassadors for Madagascar. Madagascar Conservation \& Development 1, 1: 4-8. (doi:10.4314/mcd.v1i1.44043)

UNDP. 2013. Human Development Report. 2013. The Rise of the South: Human Progress in a Diverse World. United Nations Development Program. Available at <http://hdr.undp.org/en/2013-report>

UNESCO-UNEP. 1975. The Belgrade Charter: A framework for environmental education. Available at <unesdoc.unesco.org/images/0001/000177/017772eb.pdf>

Villamanga, A. M. and Murphy, B. R. 2010. Ecological and socio! economic impacts of invasive water hyacinth (Eichhornia crassipes): a review. Freshwater Biology 55, 2: 282-298. (doi:10.1111/j.1365-2427.2009.02294.x)

Waeber, P. O. and Hemelrijk, C. K. 2003. Female dominance and social structure in Alaotran gentle lemurs. Behaviour 140, 10: 1235-1246. (doi:10.1163/156853903771980576)

Waeber, P. O. and Wilmé, L. Madagascar rich and intransparent. 2013. Madagascar Conservation \& Development 8, 2: 52-54. (doi:10.4314/mcd.v8i2.1)

Waeber, P. O., Wilmé, L, Mercier, J.-L., Rakotozafy, L. M. A., Garcia, C. and Sorg, J-P. $2015 a$ (In press). The role of lakes in the context of the centers of endemism. Akon'ny Ala.

Waeber, P. O., Ratsimbazafy, J. H., Andrianandrasana, H., Ralainasolo, F. B., Nievergelt, C. M. 2015b (In press). Hapalemur alaotrensis, a conservation case study from the swamps of Alaotra, Madagascar. In: Primates in Flooded Habitats: Ecology and Conservation. A. Barnett, I. Matsuda and K. Nowak (eds.). Cambridge University Press.

Waeber, P. O., Ralainasolo, F. B., Ratsimbazafy, J. H., Nievergelt, C. M. 2015c (In press). Consequences of lakeside living for the diet and social ecology of the lake Alaotran gentle lemur. In: Primates in Flooded Habitats: Ecology and Conservation. A. Barnett, I. Matsuda and K. Nowak (eds.). Cambridge University Press.

Wallace, A. P. C. 2012. Understanding Fishers' Spatial Behavior to Estimate Socia Costs in Local Conservation Planning. Unpubl. Ph.D. thesis. Department of Ecology and Evolution, Imperial College London, UK.

Whyte, W. F. E. 1991. Participatory Action Research. Sage Publications, Inc. 